\title{
Assessment of knowledge and practice of nurses on initial management of acute poisoning in Dessie referral hospital Amhara region, Ethiopia, 2018
}

\author{
Ayele Mamo Abebe ${ }^{1 *}$ D, Mesfin Wudu Kassaw² and Nathan Estifanos Shewangashaw ${ }^{2}$
}

\begin{abstract}
Introduction: Poisoning is a major health problem worldwide, and it causes significant morbidity and mortality. It is estimated that 350,000 people died worldwide from unintentional poisoning. The purpose of this study is to assess nurses' knowledge and practice on the initial management of acute poisoning among nurses in Dessie referral hospital, Amhara region, Ethiopia.

Methods: Hospital based cross sectional study was conducted from January 2018 to June 2018. Simple Random sampling technique was used to select the samples. Data was collected by using self-administered structured questioners. Data were cleansed, checked for completeness and entered into SPSS version 20 for analyses. Statistical measures of Central tendency, T-test and ANOVA were used in determining the association between independent and dependent variables.

Results: Based on the given 13 items to assess the general knowledge of nurses on poisoning, the score ranges from 2 to 9 with the range of 7 with the mean score of 7.48(SD-0. 0.839) for the entire respondents that was $57.5 \%$ for the given items that was less than $75 \%$ which was unsatisfactory level of knowledge. The mean score of general knowledge on poisoning was high among nurses who had training on initial management of poisoning than those nurses who had not the training.

Conclusion and recommendation: All Dessie referral nurses that participated in this study had unsatisfactory general knowledge on poisoning, knowledge on initial management of acute poisoning and self-reported practice. The major implication of these study findings on the health system is the importance of ensuring support to nurses' health care services for early detection and management of poisoning.
\end{abstract}

Keywords: Knowledge, Practice, Poisoning, Management, Nurses

\section{Introduction}

Poison may be defined as any substance that can harm, kill by producing general or local destruction in the body [1-3]. It happens by the absorption of substances into the body to causing damage to the body cells $[4,5]$.

Poisoning is a major health problem worldwide $[3,6]$. There are more than three million poisonings with 251, 881 deaths occurring worldwide annually and $99 \%$ of the

\footnotetext{
*Correspondence: ayelemamo12@gmail.com

'Primary author: Department of nursing, Debre Birhan Health Sciences College, 37 Debre Birhan, Amhara, Ethiopia

Full list of author information is available at the end of the article
}

death occurs in developing countries [6]. In developed countries, acute poisoning is the leading cause for a visit to the emergency department among patients aged 2 to 30 years whereas, in developing countries, it is the second most common cause following infectious disease [7-9]. Death is higher in developing countries due to acute poisoning [10].

As WHO report, of all case deaths due to acute poisoning, Africa accounts 8\% and Kenya 3.13\% in 2015 [11]. According to a study in Ethiopia that revealed the highest proportion of poisonings happened in adults in which fatality rate was from $2.4-8.6 \%$ [12].

(c) The Author(s). 2019 Open Access This article is distributed under the terms of the Creative Commons Attribution 4.0 International License (http://creativecommons.org/licenses/by/4.0/), which permits unrestricted use, distribution, and reproduction in any medium, provided you give appropriate credit to the original author(s) and the source, provide a link to the Creative Commons license, and indicate if changes were made. The Creative Commons Public Domain Dedication waiver (http://creativecommons.org/publicdomain/zero/1.0/) applies to the data made available in this article, unless otherwise stated. 
Acute drug poisonings account for nearly half of all poisonings reported [13-15]. Half a million people die annually due to poisoning [16]. WHO reported that acute poising is accounted $0.5 \%$ of intentional and unintentional injuries in Ethiopia, in 2012 [17-21]. Emergency department's (ED) nurses should be equipped with the professional knowledge and skills to enable them to deal with a poisoned patient, and to assess the patients' and family structure professionally [12, 22, 23].

According to the study done in Kenya, 51.5\% of nurses were aware that women were more likely to take poison than men. About $64.7 \%$ of nurses had shown euthanasia when they got poisoning patient [24]. In Another study, the mean scores for acute poisoning knowledge practices ranged from 7.2 among certificate nurses to 7.4 for higher diploma \& degree nurses [25].

Based on a study conducted in Egypt, all nurses in the studied sample $(100 \%)$ had unsatisfactory knowledge level $(<75 \%)$ regarding detection and management of acute drug poisoning [26]. Similarly, in Hawassa study, All ED nurses that participated in the study had unsatisfactory knowledge $(<75 \%)$ [27]. since there was no study done in the study area, the findings of the study were very important to identify the factors of knowledge and practice of acute poisoning management.

\section{Method and material}

\section{The study area and period}

The cross-sectional study design was conducted in Dessie referral hospital, Amhara region, Ethiopia from January 2018 to June 2018. Dessie referral hospital is located $401 \mathrm{~km}$ to the North of Addis Ababa, the capital city of Ethiopia and $475 \mathrm{~km}$ far from Bahir Dar which is the capital city of Amhara region. The Source Population was all BSc and Diploma staff nurses who have been working in Dessie referral hospital.

\section{Sample size determination and sample procedure}

To determine the sample size for the study, the following assumptions were considered:

$P=61.5 \%$ percentage of a proportion of nurses those have adequate knowledge poisoning management in Ethiopia from Hawassa study in 2016 was taken.

$5 \%$ margin of error $(d=0.05)$.

\section{$10 \%$ for non-response rate}

The Sample size was calculated by using the formula:

$$
\mathrm{ni}=\frac{\mathrm{z}^{2} \mathrm{p}[1-\mathrm{p})}{\mathrm{d}^{2}}
$$

Where $\mathrm{n}=$ sample size.

$$
\begin{aligned}
\mathrm{n}_{\mathrm{i}}= & (1.96) \times(1.96) \\
& \times 0.615(0.385) /(0.05)(0.05) \text { for population. } \\
= & 363
\end{aligned}
$$

But our study population 256 total number of nurses in DRH is less than 10,000 the calculation was processed with reduction i.e. $n f=n i /\left(1+\frac{n i}{N}\right)=363 /\left(1+\frac{363}{256}\right)=$ 150 , and we add a non-respondent rate of $10 \%$ so final sample size was165.

\section{Sampling procedure}

All 256 nurses working in the Dessie referral hospital was considered for the study. Participants were selected by using simple random sampling technique from each department based on proportion until the required sample size obtained (Fig. 1).

\section{Data collection procedure}

The questionnaires were developed in English that includes all the relevant variables to meet the objective of the study. The data collected for this study was out by using a self-administered structured questionnaire.

\section{Data quality control}

The questionnaire was pretested before the actual data collection by taking around $5 \%$ of the total calculated sample size in Kombolcha health center to check consistency, validity, and acceptability of the questioners. The Cronbach alpha result was 0.75 which showed the strong validity and reliability of the questionnaire.

\section{Data processing and analysis}

The data was entered and analyzed through SPSS 20. A $P$-value less than 0.05 was cut point to say there was a positive association $\mathrm{b} / \mathrm{n}$ the dependent and independent variables. Finally, the result was presented using frequency, percentage, tables, and graphs.

\section{Results}

Socio-demographic characteristics of the study participants From a total of 165 participants recruited, 160 participated in the study while 5 unwilling to participate in the study, yielding the response rate of $97.0 \%$. Among the 160 study participants, $96(60.0 \%)$ were males. Majority of the respondents, 110(68.8\%) were BSc holder (Table 1).

\section{Response of DRH nurses on their general knowledge of the poisoning}

The item for which nurses displayed the highest knowledge level was on the definition of poison which was 138(86.3\%).The item with lowest knowledge level was both classification of poison-based on its motive and cause, and alimentary signs and symptoms of acute poisoning at an early stage; which was homicidal poisoning 


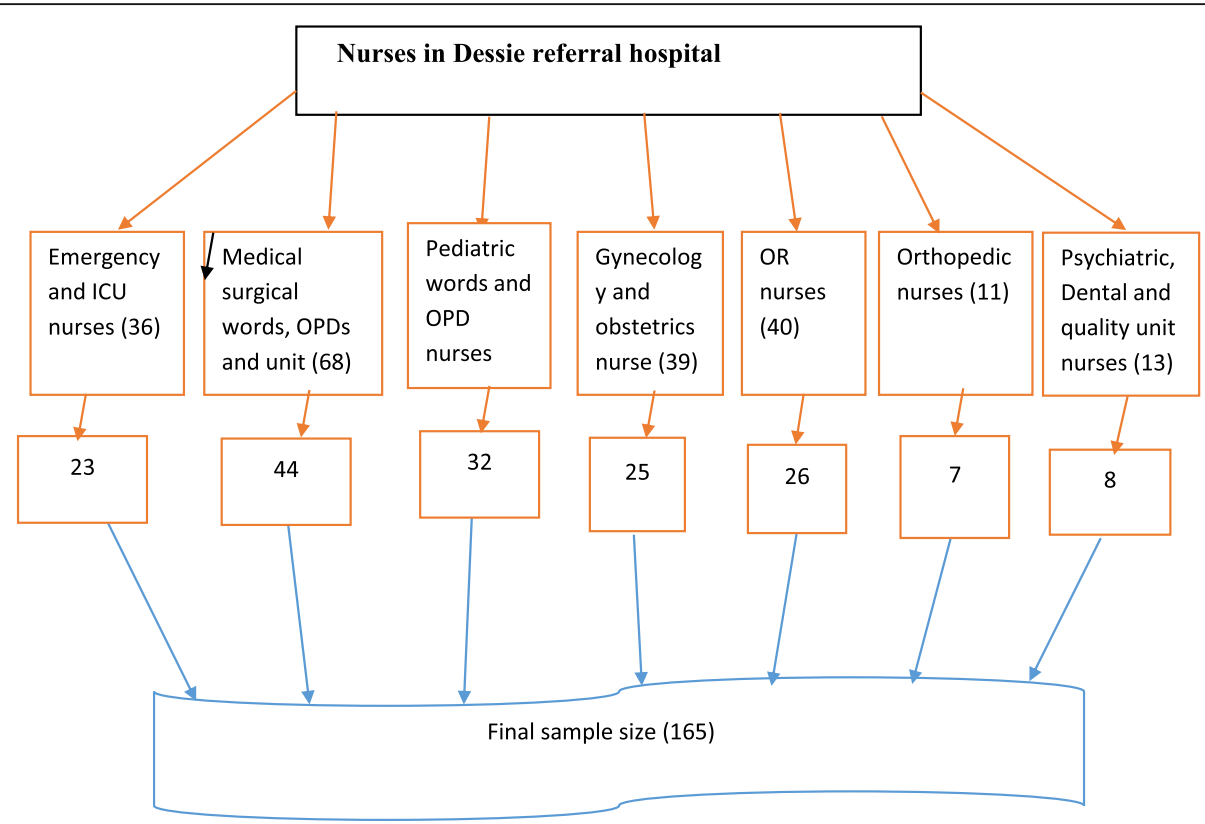

Fig. 1 Sampling procedure participants in Dessie referral hospital

Table 1 The socio-demographic, experience and training of study participants Dessie referral hospital, North Eastern Amhara region, Ethiopia, $2018(n=160)$

\begin{tabular}{|c|c|c|}
\hline Variables & Frequency $(n=160)$ & Percent (\%) \\
\hline \multicolumn{3}{|l|}{ Sex } \\
\hline Male & 96 & 60.0 \\
\hline Female & 64 & 40.0 \\
\hline \multicolumn{3}{|l|}{ Age } \\
\hline $20-29$ & 122 & 76.3 \\
\hline $30-39$ & 28 & 17.5 \\
\hline $40-49$ & 7 & 4.4 \\
\hline$>50$ & 3 & 1.9 \\
\hline \multicolumn{3}{|c|}{ Educational Level } \\
\hline Diploma & 49 & 30.6 \\
\hline Bsc & 110 & 68.8 \\
\hline Msc & 1 & 0.6 \\
\hline \multicolumn{3}{|c|}{ Length of experience } \\
\hline$<3$ years & 112 & 70.0 \\
\hline $4-10$ years & 46 & 28.8 \\
\hline $11-15$ years & 1 & 0.6 \\
\hline$>15$ years & 1 & 0.6 \\
\hline \multicolumn{3}{|c|}{ Training on management of acute poising } \\
\hline No & 69 & 43.1 \\
\hline Yes & 91 & 56.9 \\
\hline
\end{tabular}

Bsc Bachelor of Science, Msc Master of Science
20(12.5\%) and Dry mouth, abdominal pain and salivation $30(18.8 \%)$ respectively (Table 2 ).

\section{DRH nurses responses on initial management of acute} poisoning practices

Hundred forty-eight(92.5\%) of nurses answered correctly on the initial management of poisoning were on item said during organophosphate poisoning atropine should not be administered in any circumstance and the decision to perform gastro-intestinal decontamination $125(78.1 \%)$ and the volume of lavage fluid which was 102(63.7\%). The least answered was an indication of gastric lavage which was 51(31.9\%) (Table 3).

\section{Self-reported nursing practice}

Out of 160 nurses participated in the study, 49(32\%) participants were responded that guidelines or flow charts were available at facility and 100(62\%) nurses indicated that guidelines were necessary to assist in the management of poisoned casualty. One hundred twenty-one (76\%) require trained or experienced staff while responding to poison-related cases (Fig. 2).

\section{General knowledge on poisoning, knowledge on initial management of acute poisoning and self-reported practice among nurses in Dessie referral hospital} Based on this study, the score ranges from 2 to 9 with the range of 7 with the mean score of 7.48(SD-0. 0.839) for the entire respondents which were $57.5 \%$.This was less than $75 \%$ which was an unsatisfactory level of knowledge (Table 4). 
Table 2 Response of DRH nurses on their general knowledge of poisoning, Dessie referral hospital, North Eastern Amhara region, Ethiopia, 2018

\begin{tabular}{|c|c|c|}
\hline Knowledge on poisoning & Frequency correct response & Percent (\%) \\
\hline $\begin{array}{l}\text { Poison is any substance capable of producing damage or dysfunction } \\
\text { in the body by its chemical activity. }\end{array}$ & 138 & $86.3 \%$ \\
\hline $\begin{array}{l}\text { Dose ingested and time of ingestion are not very necessary consideration } \\
\text { when managing poisoning cases in ED. }\end{array}$ & 48 & $30.0 \%$ \\
\hline As an ED nurse it is always very important to treat the poison not the patient. & 55 & $34.4 \%$ \\
\hline The commonest cause of poisoning in developing countries is pesticide poisoning. & 93 & $58.1 \%$ \\
\hline $\begin{array}{l}\text { Women are more likely to take deliberate poison in general population } \\
\text { to commit suicide than men. }\end{array}$ & 129 & $80.6 \%$ \\
\hline \multicolumn{3}{|c|}{ Cause of poisoning among casualties attending any ED, according to motive and nature of use, can be classified as: } \\
\hline I. Deliberate poisoning. & 46 & $28.8 \%$ \\
\hline II. Accidental poisoning. & 65 & $40.6 \%$ \\
\hline III. Homicidal poisoning. & 20 & $12.5 \%$ \\
\hline IV. Euthanasia poisoning. & 56 & $35 \%$ \\
\hline \multicolumn{3}{|l|}{ Alimentary signs and symptoms of acute poisoning during early stages include: } \\
\hline I. Dry mouth, abdominal pain and salivation. & 30 & $18.8 \%$ \\
\hline II. Nausea, vomiting, hallucinations and convulsions. & 63 & $39.3 \%$ \\
\hline III. Coughing, cyanosis, hyperventilation and salivation. & 61 & $38.1 \%$ \\
\hline IV. Tachycardia, hypotension, diarrhea and breathlessness. & 50 & $31.2 \%$ \\
\hline
\end{tabular}

Table 3 DRH nurses responses on initial management of acute poisoning practices, North Eastern Amhara region, Ethiopia, 2018

\begin{tabular}{|c|c|c|}
\hline DRH nurses responses on IMAP practice & Frequency Correct response & Percent (\%) \\
\hline $\begin{array}{l}\text { 1-In severe acute poisoning, maintaining adequate airway, respiration and } \\
\text { circulation are always a priority.(T) }\end{array}$ & 61 & 38.1 \\
\hline $\begin{array}{l}\text { 2-In case of organophosphate poisoning atropine should not be administered } \\
\text { in any circumstance.(F) }\end{array}$ & 148 & 92.5 \\
\hline $\begin{array}{l}\text { 3-Nearly all poisoning encountered in accident and emergency department } \\
\text { have their specific antidote.(F) }\end{array}$ & 105 & 65.6 \\
\hline $\begin{array}{l}\text { 4-The decision to perform Gastrointestinal (GI) decontamination should be } \\
\text { based upon the specific poison(s) ingested, time from ingestion to presentation, } \\
\text { and the predicted severity of the poison.(T) }\end{array}$ & 125 & 78.1 \\
\hline $\begin{array}{l}\text { 5-Emesis is to be considered in an alert, conscious patient who has ingested } \\
\text { a substantial amount of a toxic substance within } 60 \mathrm{~min} \text { of presentation.(T) }\end{array}$ & 95 & 59.4 \\
\hline $\begin{array}{l}\text { 6-Activated charcoal can increase absorption of a wide range of poisons from } \\
\text { the gastro-intestinal tract to the entire human system.(F) }\end{array}$ & 71 & 44.4 \\
\hline $\begin{array}{l}\text { 7-Gastric lavage is indicated for patients who have ingested kerosene or } \\
\text { corrosive substances within an hour of presentation.(F) }\end{array}$ & 82 & 51.3 \\
\hline $\begin{array}{l}\text { 8-The effectiveness of gastric lavage increases as the time between ingestion } \\
\text { and treatment increases.(F) }\end{array}$ & 51 & 31.9 \\
\hline $\begin{array}{l}\text { 9-The volume of lavage fluid aspirated should approximate to the } \\
\text { amount of fluid given.(T) }\end{array}$ & 102 & 63.7 \\
\hline $\begin{array}{l}\text { 10-Patients presenting following ingestion of controlled/ slow released } \\
\text { substances may benefit from decontamination even after a longer delay } \\
\text { (e.g. more than } 2-4 \mathrm{~h}) .(\mathrm{T})\end{array}$ & 77 & 48.1 \\
\hline
\end{tabular}




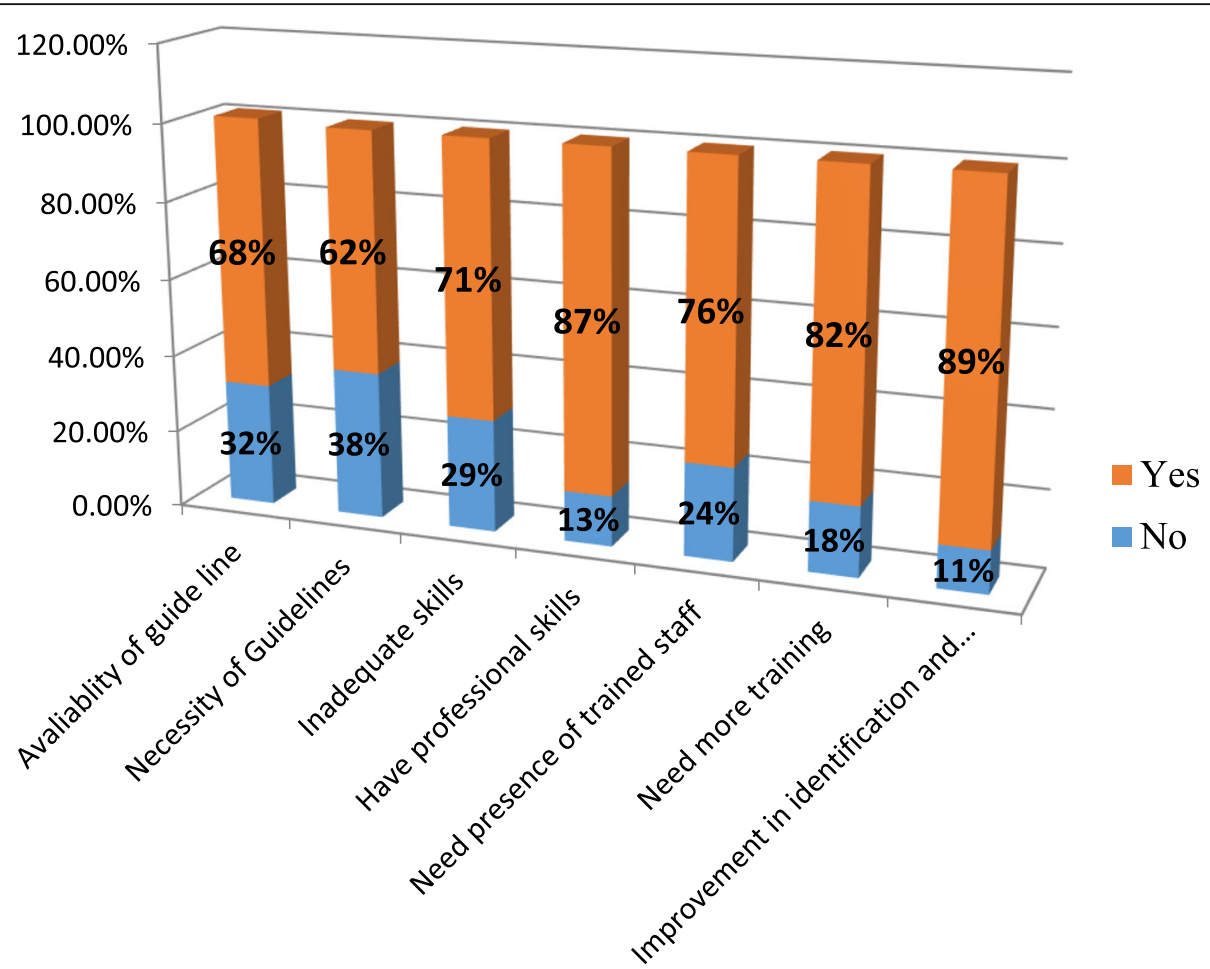

Fig. 2 Figure that show self-reported nursing practice on initial management of acute poisoning among nurses in Dessie referral hospital in $2018(n=160)$

\section{Educational status versus nurses' general knowledge of poisoning}

Diploma nurses score a mean score of 7.10(SD-0.549) which was the least score, BSc nurses score a mean of 7.65(SD-0.849) and MSc scoring a mean of 8.00 which was the highest score, the $p$-value was 0.001 (Table 5).

\section{Training versus nurses' general knowledge of poisoning}

The mean score of general knowledge on poisoning was high among nurses who had training on initial management of poisoning than those nurses who had not training (Table 6).

\section{Educational status versus knowledge on initial} management of acute poisoning

Diploma nurses score a mean of 6.65(SD-0.8), BSc nurses score a mean of 7.54(0.75) and MSc nurse score a mean of 10 being the highest score, with the mean score of 7.28(SD-0.89) and $p$-value being 0.001 which shows there was strong statistically significant association between professional qualification and general knowledge of nurses on poisoning since $\mathrm{p}$-value was $<0.05$ (Table 7).

\section{Disscussion}

The purpose of the study was to asses both nurses knowledge on general and initial management acute poisoning, self-reported practices on the initial management of acute poisoning.

According to this study, the score ranges from 2 to 9 with the range of 7 with the mean score of 7.48(SD-0. 0.839) for the entire respondents that were $57.5 \%$ for the given items that was less than $75 \%$ which was unsatisfactory level of knowledge. Similar findings were reported in many international and local studies [25-28]. The unsatisfactory level of knowledge of nurses might be related to lack of training, absence of continuous supervision and evaluation.

Table 4 General Knowledge on poisoning, knowledge on initial management of acute poisoning and self-reported practice among nurses in Dessie referral hospital, North Eastern Amhara region, Ethiopia, 2018

\begin{tabular}{lllll}
\hline & & & Range \\
& Mean Score & Standard deviation & Minimum & Maximum \\
\hline General Knowledge on poisoning & 7.48 & 0.839 & 2 & 9 \\
Knowledge on initial management of acute poisoning & 7.28 & 0.891 & 5 & 10 \\
\hline
\end{tabular}


Table 5 Educational status versus nurses general knowledge on poisoning Dessie referral hospital, north eastern Amhara region, Ethiopia, 2018

\begin{tabular}{|c|c|c|c|c|c|c|}
\hline \multirow{2}{*}{$\begin{array}{l}\text { Educational } \\
\text { status }\end{array}$} & \multirow[t]{2}{*}{ Number } & \multirow{2}{*}{$\begin{array}{l}\text { Mean } \\
(\mathrm{SD})\end{array}$} & \multicolumn{2}{|l|}{ Range } & \multicolumn{2}{|l|}{ ANOVA } \\
\hline & & & Minimum & Maximum & $p$-value & $\mathrm{F}$ \\
\hline Diploma & 49 & $7.10(0.549)$ & 6 & 8 & .001 & 7.939 \\
\hline BsC & 110 & 7.65 (0.849) & 1 & 8 & & \\
\hline Msc & 1 & 8.00 & 8 & 8 & & \\
\hline
\end{tabular}

This study had shown a strong positive association between nurses' general knowledge of poisoning and educational status. The mean score of general knowledge on poisoning was increased across the group from Diploma holder nurse to MSc holder nurses. This finding was supported by studies done in Ethiopia, Kenya and Egypt [24-27]. This indicates that a higher level of professional nursing education boosted the general knowledge of nurses regarding the management of poisoning.

Unlike this study finding from Egypt, 2012, training on primary management of acute poisoning had a significant association with nurse's general knowledge on the management of poisoning [26]. Nurses who took training on primary management of acute poisoning has a mean score of 7.64(SD-0.587) being the higher score and nurses who had no trained on initial management of acute poisoning had a mean score of 7.28(SD-1.056) being the lower score and $p$-value was 0.006 which was significant association with the dependent variable. This is reflecting that nurses can develop knowledge, skills, and understanding of patient care and treatment over time through sound educational base training.

Based on this study, the response of the nurses range between $5(\min )$ to $10(\max )$ the range was 5 and the entire mean score was 7.28 (SD-0.891) which was $73 \%$ of the given items initial management of poisoning which shows nurses had unsatisfactory knowledge on initial management of acute poisoning. Still, this study finding was much higher than the finding from Egypt; Cairo which was shown nurses' knowledge on the initial management of acute poisoning was 48.5\% [26]. This discrepancy might be due to cross-country limitations of diagnostic tools and reporting biases, differences in socio-economic environments.

According to this study, there is no significant statistical association between length of experience of nurses

Table 6 Training versus general knowledge Dessie referral hospital, north eastern Amhara region, Ethiopia, 2018

\begin{tabular}{|c|c|c|c|c|c|c|}
\hline \multirow[t]{2}{*}{ Training } & \multirow[t]{2}{*}{ Number } & \multirow[t]{2}{*}{ Mean (SD) } & \multicolumn{2}{|l|}{ Range } & \multicolumn{2}{|l|}{ ANOVA } \\
\hline & & & Minimum & Maximum & p-value & $\mathrm{F}$ \\
\hline No & 69 & $7.28(1.056)$ & 1 & 8 & .006 & 7.608 \\
\hline Yes & 91 & $7.64(0.587)$ & 7 & 8 & & \\
\hline
\end{tabular}

and their knowledge on initial management of acute poisoning. This finding is in line with findings from both Egypt [26] and Kenya [25]. This might because of the majority $(70 \%)$ of the study participants had a similar length of working experience.

Concerning about self-reported nursing practice, nearly to three fourth (68.9\%) of participants underlined there was no standard guideline in their facility for the management of acute poisoning while $62 \%$ the study participants agreed on its necessity. Such gaps also reported from the study conducted in Hawassa which showed the availability of guideline was only $16 \%$ while its necessity was reported from $43 \%$ of the study participants [27].

Comparing this study results with facilities-based crosssectional study done in Addis Ababa, we found our rates to be comparable across the board; inadequate skill $(71 \%$ vs $65 \%)$, need presence of trained staff (76\% vs $86 \%$ ), and have professional skill ( $87 \%$ vs $86 \%$,) which all revealed unsatisfactory nursing practice on the management of poisoning [27]. This difference may be due to nurses who worked in Addis Ababa had gotten more training on management of poisoned cases.

Eighty-two percent (82\%) of this study participants reported they need more training or education pertaining to the management of poison, and $89 \%$ of participant nurses indicated that it was necessary to develop procedures that improve in the identification and management of acutely poisoned casualties seen at Dessie referral hospital. It is consistent with the study results from Ethiopia, Kenya and Egypt [24-27]. This low practice levels may be related to low knowledge level and loss of continuous education and training courses. Since this was cross-sectional study design establishing a

Table 7 Educational status versus knowledge on initial management of acute poisoning Dessie referral hospital, north eastern Amhara region, Ethiopia, 2018

\begin{tabular}{|c|c|c|c|c|c|c|}
\hline \multirow{2}{*}{$\begin{array}{l}\text { Educational } \\
\text { status }\end{array}$} & \multirow{2}{*}{ Number } & \multirow{2}{*}{$\begin{array}{l}\text { Mean } \\
\text { (SD) }\end{array}$} & \multicolumn{2}{|l|}{ Range } & \multicolumn{2}{|l|}{ ANOVA } \\
\hline & & & Minimum & Maximum & p-value & $\mathrm{F}$ \\
\hline Diploma & 49 & $6.65(.805)$ & 5 & 9 & .001 & 28.772 \\
\hline BsC & 110 & $7.54(.750)$ & 6 & 10 & & \\
\hline Msc & 1 & 10.00 & 10 & 10 & & \\
\hline
\end{tabular}


temporal relationship between dependent and independent variable was impossible.

\section{Conclusions}

All Dessie referral nurses that participated in this study had unsatisfactory general knowledge on poisoning, knowledge on initial management of acute poisoning and self-reported practice. Socio-demographic and work-related characteristics such as professional qualification and training had an impact on general knowledge and initial management of poisoning. The majority of Dessie referral hospital nurses required training related to emergency and poisoning.

\section{Abbreviations}

ABC: Air way Breathing and Circulation; BSC: Bachelor of Science; ECCN: Emergency and critical care nursing; ED: Emergency Department; GCS: Glasgow Coma Scale; KAP: Knowledge attitude and practice; MSC: Master of Science; WHO: world health organization

\section{Acknowledgements}

The authors would like to acknowledge Woldia university financial support and Woldia University for providing sponsoring ship. Dessie town health Administrative office and all study participants are acknowledged for their cooperation during sample collection.

\section{Authors' contributions}

All authors wrote the research, developed the questionnaire, analyzed the data and wrote the paper and interpreting of the findings as well as participating on the preparation of the manuscript. MW and NE supervised the data collection, contributed to the interpretation of the findings. AM and NE trained data collectors, participated on the preparation of the manuscript. All authors read and approved the final manuscript.

\section{Funding}

Not funding was obtained for this study.

\section{Availability of data and materials}

All data were available in this manuscript.

\section{Ethics approval and consent to participate}

Ethical clearance was obtained from Woldia University, ethical review board and permission was given from Dessie town health administrative office and Dessie referral hospital. The research proposal was evaluated and approved by the Research Ethics Review Committee [HRERC 0810/2018] of College of Health Sciences, Woldia University. Ethical clearance was obtained. Official cooperation and permission was obtained from Dessie town health administrative office and Dessie referral hospital. The participants were guaranteed of their rights and the freedom to withdraw from the study at any time; if they did not wish to continue. A consent form was given to those who were willing to participate in the study, for them to read; and further explanations were given about the form. Each participant signed two consent forms; and was given a copy of the original signed form to keep.

\section{Consent for publication}

The article does not contain any individual's details, images or video; and hence, consent for publication is not applicable here.

\section{Competing interests}

The authors state that they have no competing interests.

\section{Author details}

${ }^{1}$ Primary author: Department of nursing, Debre Birhan Health Sciences College, 37 Debre Birhan, Amhara, Ethiopia. ${ }^{2}$ Department of nursing, College of Health Sciences, Woldia University, Woldia, Amhara, Ethiopia.
Received: 14 August 2018 Accepted: 20 November 2019

Published online: 29 November 2019

\section{References}

1. Rajanandh MG, Santhosh S, Ramasamy C. Prospective analysis of poisoning cases in a super specialty hospital in India. J Pharmacol Toxicol. 2013:8(2):60-6.

2. Chiu L, Lim B, Vasu A, Phua DH. Poison exposure in the emergency department: a Singaporean experience. Hong Kong J Emerg Med. 2011; 18(4):97-202

3. Hakim A, Khurshid R, Mufti S, Krishan K, Singh Y. Pattern, profile and outcome of poisoning cases: a study at a large teaching hospital in India. JK Pract. 2014;19(1-2):36-40.

4. Kara H, Bayir A, Degirmenci S, Akinci M, Ahmet AK, Kayis SA. Causes of poisoning inpatients evaluated in a hospital emergency department in Konya. Turkey J Pak MedAssoc. 2014;64(9):1042-8.

5. Hu Y-H, Chou H-L, Lu W-H, Huang H-H, Yang C-C, Yen DHT, Kao W-F, Deng J-F, Huang C-I (2010) Features and Prognostic Factors for Elderly With Acute Poisoning in the Emergency Department.J Chin Med Assoc. 2010:73(2):78-87.

6. Susic TP, Ketis ZK, Grzinic KM, Kersnik J. Glasgow Coma Scale in acute poisonings before and after use of antidote in patients with history of use of psychotropic agents. SrpArhCelokLek. 2010;138(3-4):210-3.

7. Carter G, Reith DM, Whyte IM, Mcpherson M. Repeated self-poisoning: Increasingseverity of self-harms a predictor of subsequent suicide. British J Psychiatr. 2005:18(6):253-7.

8. Liisanantti J. Acute drug poisoning, out come and factors affecting outcome. University of Oulu. 2010;1:68

9. Ministry of Health of Singapore(MOHS). $\mathrm{MOH}$ clinical practice guideline Dec 2011. (Available from: www.google.com). [Accessed 23 June 2017].

10. Kiran N, Rani S, Jaiprakash V. VanajaK. Pattern of poisoning reported at south Indiantertiary care hospital. Ind J Forensic Med Toxicol. 2012; 2(2):72-6.

11. World Health Organization. Poisons information, prevention and management. Geneva: WHO; 2014. p. 2014.

12. Esayas Tadesse G/Mariam and Belayneh Kefale Gelaw, Global epidemiology of acute Poisoning with an Emphasis to Ethiopia: Systematic Review. Int J Pharm Sci \& Scient Res. 2016;2:4,161-71

13. Malangu N, Ogunbanjo GA. A profile of acute poisoning at selected hospitalsin South Africa. South Africa J Epidemiol. 2009;24(2):14-6.

14. Frithsen IL, Simpson WM. Recognition and management of AcuteMedication poisoning. Am Fam Physician. 2010;81(3):316-23.

15. Bohnert AS, Fudalej S, Ilgen MA. Increasing poisoning mortality rates in theUnited States, 1999-2006. Public Health Rep. 2010;125(4):542-7.

16. Hovda KE, Bjornaas MA, Skog K, Opdahl A, Drottning P, Ekeberg O, et al. Acute poisonings treated in hospitals in Oslo: a one-year prospective study (I): pattern of poisoning. ClinToxicol. 2008;46:35-41.

17. World Health Organization (2011) Drug Poisoning visited at (16 December 2013). Retrieved from http://www.who.int/environmental_health_ emergencies/poisoning/en

18. Azazh A. Case series of 2,4-D poisoning in TikurAnbessa Teaching Hospital. Ethiop Med J. 2010:48:243-6.

19. Hutton J, Dent A, Buykx P, Burgess S, Flander L, Dietze P. The characteristics of acute non-fatal medication-related events attended by ambulance services in the Melbourne Metropolitan Area 1998-2002. Drug Alcohol Rev. 2010;29(1):53-8.

20. Koliou M, loannou C, Andreou K. PetridouA\&Soteriades ES. The epidemiology of childhood poisonings in Cyprus. Eur J Pediatr. 2010; 169(7):833-8.

21. Prescott K, Stratton R, Freyer A, Hall I, Le Jeune I. Detailed analyses of selfpoisoning episodes presenting to a large regional teaching hospital in the UK. Br J Clin Pharmacol. 2009;68(2):260-8.

22. Centers for Disease Control and Prevention (CDC). Unintentional poisoning deaths -United States, 1999-2004. MMWR - Morbid Mortal Weekl Rep. 2007; 56(5):93-6.

23. Warner M, Chen LH, Makuc DM. Increase in fatal poisonings involving opioid analgesics in the United States, 1999-2006. NCHS Data Brief. 2009;22:1-8.

24. Rutto JK. Nurse's knowledge, attitude and practice on the initial management of acute poisoning among adult casualties: study at 
accident and emergency department, Kenyatta national hospital, Kenya, 2011.

25. Rutto J, Mwaura J, Chepchirchir A, Odero T. Nurse's knowledge, attitude and practice on the initial management of acute poisoning among adult casualties: study at Kenyatta National Hospital, Kenya, 2012.

26. El Sayed Y, Youssef W, Alshekhepy HA, Elfeky H. Nurses' Knowledge and Practices regarding Detection and Management of Acute Drug Poisoning at Cairo University Hospitals, 2015.

27. Beyene $T$, Kebede $S$, Abebe A. Assessment of knowledge and practice of nurses' on initial management of acute poisoning at adult emergency department of two Public hospitals in Hawassa town, Hawassa, southern Ethiopia. 2016.

28. Greene SL, Dargan PI, Jones AL. Acute poisoning: understanding $90 \%$ of cases in anut shell. Postgrad Med J. 2005:81:204-16.

\section{Publisher's Note}

Springer Nature remains neutral with regard to jurisdictional claims in published maps and institutional affiliations.

Ready to submit your research? Choose BMC and benefit from:

- fast, convenient online submission

- thorough peer review by experienced researchers in your field

- rapid publication on acceptance

- support for research data, including large and complex data types

- gold Open Access which fosters wider collaboration and increased citations

- maximum visibility for your research: over $100 \mathrm{M}$ website views per year

At BMC, research is always in progress.

Learn more biomedcentral.com/submissions 